\title{
Yaratıcı Drama Yönteminin Öğretmen Adaylarının İletişim Becerilerine Etkisi
}

\section{Effect of Creative Drama Method on the Communication Skills of Teacher Candidates}

\author{
Mehtap Karacil Kılıçaslan \\ Kafkas Üniversitesi \\ karacil.mehtap@gmail.com
}

\author{
Ahmet Yayla \\ Van Yüzüncü Yıll Üniversitesi \\ ahmetyayla33@gmail.com
}

Alıntılama:Karacil-Kılıçaslan, M. \& Yayla, A. (2018). Yaratıcı Drama Yönteminin Öğretmen Adaylarının İletişim Becerilerine Etkisi . Ulusal Ĕgitim Akademisi Dergisi (UEAD), 2(2), 1-13.

\section{Geliş tarihi:}

15 Mart 2018

Kabul tarihi:

19 Ekim 2018

Sorumlu yazar:

Mehtap Karacil Kılıçaslan

karacilmehtap@gmail.com

(C) 2018 UEAD.

Bütün hakları saklıdır.

Özet: : Bu araştırmanın amacı; yaratıcı drama yönteminin öğretmen adaylarının iletişim becerileri üzerindeki etkisini incelemek ve ortaya koymaktır. MEB tarafından 2017 yılında güncellenen öğretmenlik mesleği genel yeterlikleri "Mesleki bilgi", "Mesleki beceri", "Tutum ve değerler" olmak üzere birbiriyle ilişkili 3 yeterlik, 11 alt yeterlik ve bu yeterliklere ilişsin 65 yeterlik göstergesinden oluşmaktadır. Tutum ve değerlerin alt yeterlik alanı olan "iletişim ve iş birliği" her öğretmenin sahip olması gereken yeterlik alanı olarak belirlenmiş̧tir (MEB, 2017). Öğretmen; öğrenci, meslektaş, aile ve eğitimin diğer paydaşları ile etkili iletişim becerisine sahip olmalıdır. Dolayısıyla bu çalışmada öğretmenlik mesleği genel yeterliklerinden iletişim becerilerinin gelişimini sağlamada yaratıcı drama yönteminin öğretmen adaylarını ne derecede etkilediğini tespit etmek amaçlanmıştır. Araştırmanın çalışma grubunu, 2016-2017 öğretim yılında, Kafkas Üniversitesi Eğitim Fakültesi Temel Eğitim Bölümü Sınıf Öğretmenliği son sınıfta öğrenim gören 68 öğretmen adayı oluşturmuştur. Araştırma karma yönteme göre desenlenmiştir. Araştırmanın nicel boyutunda (öntest-sontest-kalıcılık testi) yarı deneysel desen, nitel boyutunda odak grup görüşmesi yapılmıştır. Nicel veriler; Balcı-Çelik ve Ersanlı (1998), tarafından geliştirilen 'İletişim Becerileri Envanteri' başlıklı çalışmasından alınmıştır. Nitel veriler; araştırmacı tarafından uzman görüşleri alınarak, yarı yapılandırılmış görüşme soruları ile toplanmıştır. Araştırma sonucunda, yaratıcı drama yönteminin, öğretmen adaylarının iletişim becerilerini geliştirmede, geleneksel yönteme göre daha etkili ve kalıcı olduğu, bu yeterlikleri geliştirdiği tespit edilmiştir.

Anahtar kelimeler: Yaratıcı drama, ögretmen yetiştirme, iletişim becerileri

Received:

15 March 2018

Accepted:

19 October 2018

Corresponding author: Mehtap Karacil Kılıçaslan karacil.mehtap@gmail.com (c) 2018 UEAD.
Abstract: The purpose of this research is to demonstrate the impact of the creative drama method on the Communication Skills of preservice teachers. The general qualifications of the teaching profession updated by MEB in 2017 consist of 3 related proficiencies such as " Professional knowledge ", " Professional skills ", " Attitudes and values ", 11 sub-qualifications and including 65 proficiency indicators related to these values. 'Communication and cooperation', which is the sub-competency scope of attitudes and values, has been idendified as the competence scope that each teacher should have (MEB, 2017). Teacher should have effective communication skills with student, colleague, family and other stakeholders of the education. Therefore, in this study, it was aimed to determine the creative drama method influenced the prospective teachers in terms of the improvement of general proficiency of teaching profession of which communication skills to what extent. The study group consisted 

the Education Faculty of Kafkas University in the academic year of 2016-2017. The study was designed according to mixed method. In the quantitative dimension of the study (pretestposttest-permanence test), a focus group interview was conducted on the quasi-experimental design, qualitative dimension. The quantitative data were taken from the study titled 'Communication Skills Inventory' carried out by 'Balc1-Çelik and Ersanlı (1998)'. The qualitative data is compiled by the means of semi-structured interview questions prepared by the researcher getting the experts' opinions. The research findings indicate that the creative drama method improves the communication skills of teacher candidates and is more effective and lasting in improving this self-efficacy than the traditional method.

Keywords: Creative drama, teacher training, communication skills

\section{Giriş}

Tüm mesleklerde iletişim becerileri gerekmektedir. Fakat bazı mesleklerde iletişim becerilerinin önemi daha fazladır. Çünkü bu mesleklerin icraatleri uygulamalı insan ilişkilerine dayanmaktadır. Öğretmenlikde bu mesleklerden biridir ve öğretmenlerin etkili iletişim becerilerine sahip olmaları beklenmektedir (Dilekmen, Başçı ve Bektaş, 2008; Milli Eğitim Bakanlığı (MEB), 2017; World Bank, 2005).

Öğretmenlerin öğretmen yetiştiren kurumlardan yeterli bilgi ve becerilerle mezun olmaları beklenmektedir. Dolayısıyla öğretmenler hangi iletişim becerilerine sahip olmalıdır sorusu gündeme gelmiş ve öğretmenlerde bulunması gereken iletişim becerileri eğitim bilimlerinin önemli ve güncel bir araştırma konusu olmuştur. Öğretmenlerin eğitim-öğretim sürecinde bir fikri, düşünceyi eleştirel bir şekilde değerlendirmeleri, sorgulamaları, neden sonuç ilişkisi kurmaları etkili bir iletişim becerisiyle gerçekleştirilebilir (Elkatmış, 2015; World Bank, 2005).

İletişim becerileri diğer insanlarla ilişkilerde kendini ifade etmede, soru sorma, dinleme, konuşma, arkadaşlık kurma, hakkını savunma, başkalarının hakkına saygı duyma, değer verme, bireyleri ismiyle hitap etme, bireylerin sahip olması gereken, sonradan kazanılan ve bireyin olumlu tepkiler vermesini geliştiren becerilerdir (Dowd ve Teirney, 2005; Lavasani ve Afzoli, 2011). Bu bağlamda öğretmen yetiştiren kurumlarda öğretmen adaylarına iletişim becerileri, yeterliliklerinin kazandırılması önemlidir. Türkiyede öğretmen adaylarıyla iletişim becerilerine yönelik yapılan araştırmalarda iletişim becerileriyle ilgili sorunların olduğu görülmektedir. Söz konusu yeterlilikle ilgili literatür incelendiğinde iletişim becerilerinin öğretmen yetiştirmede önemli bir değişken olduğu tespit edilmiştir (Leffert, Brody ve Sperstein, 2009; Oğuz, 2009; Sazak vd, 2013).

Öğretmenin etkili iletişim becerisine sahip olması kişisel ve mesleki yeterlilikleri bakımından önemli bir yere sahiptir. Öğrenmenin temelinde iletişim süreci vardır. Bu süreçle gönderilen iletinin anlaşı1ır olması ögretmende bulunması gereken yeterliliklerle ilgilidir. Yani öğrencilerin kişilik ve akademik başarılarının gelişiminde öğretmenin öğrencisiyle iletişiminin etkisi büyüktür (Ergin ve Birol, 2000; Yaman ve Aydın, 2015).

İletişim becerilerinin gelişmesinde en etkili yöntem dramadır (Bell, 2008). Literatürde de iletişim becerilerin kazanılmasında yaratıcı dramanın etkili bir yöntem olarak kullanılabileceğine ilişki çalışmalar mevcuttur (Bayraktar ve Okvuran, 2012; Karacil, 2009; Mantione \& Smead, 2003; McNoughton, 2004; Rances, 2005; Saçl1, 2013; Üstündağ 2004).

İletişim, yaratıcı dramanın hem amaçlarına ulaşmada bir araç, hem de dramanın araçlarında yer alan boyutlardan biridir. İletişim yaratıcı drama süreçlerine katılan tüm bireyler 
için önemlidir. Yaratıcı drama uygulamaları ile bireyler etkili iletişim kurma becerisi kazanıp geliştirir. Yaratıcı drama çalışmalarında bireyler çeşitli amaçlar için hem kendisiyle hem de gruptakilerle iletişime geçmesi gerekir. İletişim yaratıcı drama uygulamalarında bireylere kazandırılması gereken önemli bir beceridir (Adıgüzel, 2013).

Yaratıcı drama ve iletişim becerilerine baktığımızda birey yaratıcı dramada aktiftir. Jest ve mimiklerini, ses tonunu, vurgulamayı iyi kullanır. Bireyler yaratıcı drama yöntemiyle duygu ve düşüncelerini karşı tarafa etkili şekilde iletir. Üstündağ (2006)'a göre, eğitimde yaratıcı drama kullanılmasının ilk yararı kişinin kendisini gerçekleştirmesine firsat vermesidir. Kendini gerçekleştirmiş eleştiriye açık, iletişim becerisi gelişmiş, kendi kapasitesinin farkına varıp bunu kişisel ve mesleki hayatında ortaya koyan yaratıcı, üretken, duygu ve düşüncelerini iyi ifade eden kişidir. Bireyin kendini ve başkasını tanıması, empati kurma, kendi yeterliliğinin farkına varma, yaratıcı ve eleştirel düşünme becerisi kazanma, işbirliği içinde çalışma yeteneği kazanma, öz güven kazanma, etkili iletişim becerileri geliştirme, hayal gücü ve yaratıcılık geliştirme, karar verme becerilerini geliştirme, problem çözme becerilerini geliştirme yaratıcı dramanın genel amaçlarındandır. Dolayısıyla yaratıcı drama yöntemi sayesinde, bireylerin iletişim becerileri gelişir (Adıgüzel, 2013; Köksal, 2007; San, 2003; Tuğrul, 2003; Üstündağ, 2004).

$\mathrm{Bu}$ bağlamda yaratıcı drama yönteminin içeriği ile iletişim becerilerin içeriği benzerlik göstermektedir. Yaratıcı drama uygulamalarında bireyler tüm duyularını kullanmayı öğrenirler. Bedenin rahat kullanılması, duruş, jestler, giysi, aksesuar seçme gibi sözel olmayan iletişim becerilerini geliştirirler. İletişim becerilerinin geliştirilmesinde önemli yere sahip olan yaratıcı dramada öğretmen yetiştirme lisans programlarında yer verilmesi, öğretmen adaylarının iletişim beceri ve yeterliliklerinin gelişmesine katkı sağlayacaktır (Üstündağ, 2007).

Geçmişten günümüze eğitim sistemlerinde meydana gelen değişim, öğretmen yetiştirmede de değişimi zorunlu kılmaktadır. Çağdaş eğitimde öğretmen yetiştirmedeki değişiklik, öğretmen yeterliklerinde de değişikliğe sebep olmuştur. Eğitim Programları ve öğretim alanında öğretmen yeterlilikleri sıklıkla incelenen ve araştırılan bir konudur. Özellikle öğretmen yeterliliklerinin nasıl olması gerektiği konusunda bugüne kadar yapılmış çalışmalar bulunmaktadır (Erden, 1998; Gordon, 2010; Lunenberg, 2002; Sönmez, 2003; Sünbül, 2006; Tan-Şişman, 2017; YÖK, 1998). Fakat öğretmen yeterliklerinden kişisel ve mesleki yeterlik göstergesi olan iletişim becerilerini yaratıcı drama yöntemiyle kazandırma ve yaratıcı drama yönteminin eğitim programları ve öğretim alanındaki önemiyle ilgili yeterli çalışmaya rastlanmamıştır. Bu nedenle öğretmen yetiştirme programlarında, yaratıcı drama yönteminin kullanılması, öğretmen yeterliklerini kazandırırken karşılaşılan sorunların çözümü ve programların gelişimi açısından etkili olabilir (Adıgüzel, 2013).

Öğretmenin etkili iletişim becerisine sahip olması kişisel ve mesleki yeterlilikleri bakımından önemli bir yere sahiptir. Bu bağlamda öğretmen yetiştiren kurumlarda öğretmen adaylarına iletişim becerilerinin kazandırılması önemlidir. Ülkemizde öğretmen adaylarıyla iletişim becerilerine yönelik yapılan araştırmalarda iletişim becerileriyle ilgili sorunların olduğu görülmektedir. Söz konusu yeterlilikle ilgili literatür incelendiğinde iletişim becerilerinin öğretmen yetiştirmede önemli bir değişken olduğu tespit edilmiştir (Leffert, Brody ve Sperstein, 2009; Oğuz, 2009; Sazak vd, 2013). 


\subsection{Araştırmanın Amacı}

Yaratıcı drama yönteminin öğretmen adaylarının iletişim becerileri üzerindeki etkisini incelemek ve ortaya koymaktır.

\subsection{Araştırmanın Problemi}

Belirtilen amaç doğrultusunda araştırmanın problemi "Yaratıcı drama yönteminin öğretmen adaylarının iletişim becerileri üzerindeki etkisi var mıdır? şeklindedir. Araştırma problemi doğrultusunda belirlenen alt problemleraşağıda belirtilmiştir:

1. Deney ve kontrol grubu iletişim becerileri ön test puanları arasında anlamlı fark var mıdır?

2. Deney grubu iletişim becerileri öntest/ sontest puanları arasında anlamlı fark var mıdır?

3. Kontrol grubu iletişim becerileri öntest/ sontest puanları arasında anlamlı fark var mıdır?

4. Deney ve kontrol grubu iletişim becerileri sontest puanları arasında anlamlı fark var mıdır?

5. Deney grubu iletişim becerileri öntest, sontest, kalıcılık puanları zamanla anlamlı fark var midir?

\section{Yöntem}

Bu bölümde araştırma modeli, evren ve örneklem, verilerin toplanması ve verilerin analizi yer almaktadır

\subsection{Araştırma Modeli}

Araştırmada karma araştırma modelinden, gömülü desen kullanılmıştır. Karma yöntemin amacına göre, gömülü yöntemde nitel veriler, nicel verilerin güvenilirliğini desteklemek için kullanılmıştır (Creswell, 2008). Araştırmanın nicel kısmında yarı deneysel desen, nitel kısmında odak grup görüşmesi yapılmıştır. Araştırmada, nicel yöntemde "öntest", "sontest" ve "kalıcılık testi", deney/kontrol gruplu deneme modeli kullanılmıştır. Nitel yöntemde, kalıcılık testi güvenilirliğini artırmak için deney grubunda odak grup görüşmesi yarı yapılandırılmış görüşme formu uygulanmıştır Çalışmanın bağımsız değişkenleri "Yaratıcı Drama Yöntemi” "Düz AnlatımYöntemi"; bağımlı değişkeni "İletişim Becerileri” dir.

\subsection{Araştırma Grubu}

Araştırma grubunu 2016-2017 eğitim-öğretimgüz yarıyılı Kars Kafkas Üniversitesi Eğitim Fakültesi Temel Eğitim Bölümü 4. sınıfta öğrenim gören 68 öğretmen adayı oluşturmuştur.

\subsection{Veri Toplanmasl}

Öğretmen adaylarının iletişim becerilerini belirlemek amacıyla nicel veriler; Balcı-Çelik ve Ersanlı (1998), tarafından geliştirilen 'İletişim Becerileri Envanteri' başlıklı çalışmasından alınmıştır. Ölçek, beşli Likert tipi derecelendirme ölçek olup "hiç katılmıyorum" (1), "katılmıyorum (2)", "kararsızım (3)", "katılıyorum (4)" "tamamen katılıyorum (5)" biçiminde derecelendirilmiştir. Araştırmada kullanılan ölçekte, Test yarılama yöntemi güvenirlik çalışmasında $r=64$, test tekrar test $r=70$ bulunmuştur. Daha sonra aynı envanter üniversite öğrencileri üzerinde uygulanmış olup Cronbach Alpha 0,85 olarak çıkmıştır. Korelasyon 0.01 
düzeyinde anlamlı çıkmış olması bölümün niteliğine uygun maddelerden oluştuğunu göstermektedir (Balcı-Çelik ve Ersanlı, 1998). Bu araştırmada 45 maddelik iletişim iç tutarlığını belirlemek için yapılan Cronbach Alpha katsayısı .98 bulunmuştur. Bu bulgu güvenilirliğin oldukça yüksek olduğunu ve ölçeğin kullanılabilir düzeyde olduğunu göstermektedir. Nitel veriler ise araştırmacı tarafından uzman görüşleri alınarak hazırlanan yarı yapılandırılmış görüşme soruları veri toplama aracı olarak kullanılmıştır.

İslem Basamakları:

Öğretmen adaylarına iletişim becerileri ölçeği ön test uygulanarak, başlangıç itibariyle giriş davranışları bakımından birbirine denk olduğu kanaatine varılan iki şube, kura yöntemiyle deney ve kontrol grubu olarak belirlenmiştir. Uygulamaya başlamadan önce araştırmacı tarafından uzman görüşü alınıp, drama aşamaları göz önüne alınarak 14 oturumluk 42 saatlik yaratıcı drama etkinlik planı hazırlanmışıtır. Etkili iletişim dersi kapsamında, deney grubundaki öğretmen adaylarına yaratıcı drama yöntemi, kontrol grubundaki öğretmen adaylarına düz anlatım yöntemi uygulanmıştır

Deney grubunda, hazırlanan etkinlik planları belirlenen ders saatlerinde, Etkili İletişim dersinde yaratıcı drama yöntemi ile uygulanmıştır. Kontrol grubunda ise, Etkili iletişim dersi düz anlatım yöntemi ile işlenmiştir. Süreç bitiminde deney grubu ve kontrol grubuna iletişim becerileri ölçme aracı sontest uygulanmıştır. Son test uygulandıktan 8 hafta sonra deney grubundaki öğretmen adaylarına için kalıcılık testi ve odak grup görüşmesi yapılmıştır.

\section{Odak grup görüşmesi}

Deney grubunda kalıcılık testi iletişim becerileri ölçme aracının, daha önce öntest ve son test olarak uygulanması, diğer deyişle aynı ölçme aracının üç kez uygulanması, öğretmen adaylarının bu ölçme aracına yönelik farkındalıklarının artırmasına sebep olduğu düşünülebilir. $\mathrm{Bu}$ sebeple, deney grubuna kalıcılık testi uygulandıktan sonra, öğretmen adaylarıyla odak grup görüşmesi yapılmış, yarı yapılandırılmış açık uçlu görüşme soruları geliştirilmiştir. Görüşme soruları geliştirilirken birden fazla uzman görüşü alınmıştır. Yarı yapılandırılmış görüşme formu deney grubundan 10 gönüllü ögretmen adayıyla bir araya gelinerek, yüz yüze iletişim şeklinde uygulanmıştır. Görüşmeler video kameraya alınmış ve yaklaşık bir saat sürmüştür. Yaratıcı drama yönteminin iletişim becerileri gelişimi üzerinde ne derece etkili olduğu, içerik analizinde elde edilen sonuçların frekanslarıyla ve öğretmen adaylarının görüşmelerdeki söylemleriyle açıklanmıştır.

\subsection{Verilerin Analizi}

Araştırmanın amacı doğrultusunda nicel veriler SPSS 22.0 istatistik programında, nitel veriler içerik analizi ile analiz edilmiştir. Nicel verilerin analizinde; normallik testi analizi, ölçme aracının güvenilirlik analizi, bağımsız (independent samples) ve bağımlı gruplar (paired samples) t-testi, tekrarlı ölçümler ANOVA bonferroni testi analizi yapılmıştır.

Nitel verilerin analizinde, odak grup görüşmeleri, içerik analiziyle yöntemiyle analiz edilmiştir. Nitel veri işlem basamağı; Araştırmacı tarafından veri toplamada kullanılan ölçeğin maddeleri göz önüne alınarak toplam üç adet açık-uçlu sorudan oluşan bir ölçme aracı hazırlanmıştır. İç geçerliği sağlamak için açık uçlu sorulardan oluşan anket üç uzmana verilmiş̧ ve uzmanların incelemeleri sonucu sorulara son şekli verilmiştir. Öğretmen adaylarının sorulara vermiş olduğu cevaplardan deşifre edilen cümleler ilgili kategorilerin altına yazılmıştır. Öğretmen adaylarına hazırlanan ölçme aracı yoluyla şu sorular yöneltilmiştir: 
1. Etkili iletişim dersinin iletişiminiz üzerinde olumlu, olumsuz ya da nötr etkisi olmuş mudur, açıklayınız?

2. Drama yöntemi hakkında fikirlerinizi söyler misiniz?

3. Etkili iletişim dersinde kullanılan yöntemin etkisini "Anlayış, sabır, hoşgörü, öz güven, kendini ifade etme, eleştirme, dinleme, beden dili, ses tonu, konuşma, anlaşılma, özür dileme, sosyallik.”açısından öz değerlendirme yaparak açıklar mısınız?

Uygulama sonrasında, öğretmen adaylarının açık-uçlu sorulara verdikleri yanıtlar hem araştırmacı hem de araştırmacı dışında bir öğretim üyesi tarafından ayrı ayrı incelenmiştir. Elde edilen veriler ışı̆̆ında oluşturulan temalar kapsamında "görüş birliğĭ" ve "görüş ayrılığı" olan konular tartışılmış; soruların cevaplarının ortak tema ve alt temalar altında toplanması kararı alınarak gerekli düzenlemeler yapılmıştır. Araştırmanın güvenilirlik hesaplaması için Miles ve Huberman'ın (1994) önerdiği güvenirlik formülü kullanılmıştır. Güvenirlik = Görüş Birliği / (Görüş Birliği + Görüş Ayrılığı) Hesaplama sonucunda araştırmanın güvenirliği \% 90 olarak hesaplanmıştır. Güvenirlik hesaplarının \%70'in üzerinde çıkması, araştırma için güvenilir kabul edilmektedir (Miles ve Huberman, 1994). Burada elde edilen sonuç, araştırma için güvenilir kabul edilmiştir.

Nitel verilerin analizinde her kategorinin frekansları hesaplanmış, uygulanan kalıcılık testi sonuçlarıyla çalışmanın güvenirliği açısından karşılaştırılmıştır.

\section{Bulgular}

Veriler analiz edilirken öncelikle normallik dağılımına bakılmıştır. Normallik istatistiklerinde değerlendirme birimleri basıklık ve çarpıklık katsayıları analiz edilmiştir. Değerlerin \pm 1.50 aralığında olması, dağılımın normal durumdan aşırı sapma göstermediğinin kanıtıdır (Tabachnick ve Fidell, 2012). Normallik analizi sonucunda deney ve kontrol gruplarının iletişim becerileri öntest kurtosis (basıklık) ve skewnes (çarpıklık) değerleri ölçülmüş değerler \pm 1.50 arasında normal dağılım gösterdiği için gruplar arası bağımlı ve bağımsız t-testi kullanılmıştır bağımsız t testine geçilmiştir. Çalışmada iletişim becerileri ölçeğinden elde edilen veriler normal dağılım gösterdiğinden dolayı parametrik testler kullanılmıştır.

Tablo 1: Deney/Kontrol grubu iletişim becerileri öntest puanları bă̆ımsız gruplar (independent samples) t-testi

\begin{tabular}{lcccccc}
\hline \multicolumn{1}{c}{ Grup } & $\mathbf{N}$ & $\bar{X}$ & SS & Sd & t & p \\
\hline $\begin{array}{l}\text { Deney } \\
\text { Grubu(DG) }\end{array}$ & 34 & 2.636 & .271 & 66 & -.158 & $\mathbf{. 5 5 9}$ \\
$\begin{array}{l}\text { Kontrol } \\
\text { Grubu(KG) }\end{array}$ & 34 & 2.602 & .211 & & & \\
\hline
\end{tabular}

Tablo 1' de, deney/ kontrol grupları iletişim becerileri öntest bağımsız gruplar t-testi yapılmıştır. Deney/ kontrol öntest puanları arasında anlamlı fark bulunmamıştır $[\mathrm{t}(66)=-.158$, $\mathrm{p}>0.001]$. 
Yaratıcı Drama Yönteminin Öğretmen Adaylarının İletişim Becerilerine Etkisi

Tablo 2: Deney grubu iletişim becerileri öntest/ sontest puanları bă̆ımlı gruplar (paired samples) t-testi

\begin{tabular}{lllllll}
\hline \multicolumn{1}{c}{ DG } & N & $\bar{X}$ & SS & sd & T & p \\
\hline Öntest & 34 & 2.636 & .271 & 33 & -27.9 & $\mathbf{. 0 0 0 *}$ \\
Sontest & 34 & 4.143 & .150 & & & \\
\hline
\end{tabular}

$\left({ }^{*} \mathrm{p}<0.001\right)$.

Tablo 2' de, deney grubu iletişim becerileri öntest, sontest bağımlı gruplar testi yapılmıştır. Deney grubu öntest, sontest puanları arasında anlamlı fark bulunmuştur $[\mathrm{t}(33)=-27.9$, $\mathrm{p}<0.001]$.

Tablo 3: Kontrol grubu iletişim becerileri öntest/sontest puanlarına ait bă̆ımlı gruplar (paired samples) t-testi

\begin{tabular}{lcccccc}
\hline \multicolumn{1}{c}{ KG } & N & $\bar{X}$ & SS & sd & t & p \\
\hline Öntest & 34 & 2.602 & .211 & 33 & -4.6 & $\mathbf{. 0 0 0 *}$ \\
Sontest & 34 & 2.803 & .153 & & & \\
\hline
\end{tabular}

$(* \mathrm{p}<0.001)$

Tablo 3'de, kontrol grubu iletişim becerileri öntest/sontest bağımlı gruplar t-testi yapılmıştır. Kontrol grubu öntest/sontest puanları arasında anlamlı fark bulunmuştur [t(33)= -4.6, $\mathrm{p}<0.001]$.

Tablo 4: Deney/Kontrol grubu iletişim becerileri sontest puanlarına ait bă̆ımsız gruplar (independent samples) t- testi

\begin{tabular}{lcccccc}
\hline \multicolumn{1}{c}{ Grup } & N & $\bar{X}$ & SS & sd & t & p \\
\hline DG & 34 & 4.143 & .150 & 66 & -36.2 &. $\mathbf{0 0 0} *$ \\
KG & 34 & 2.803 & .153 & & & \\
\hline
\end{tabular}

$(* \mathrm{p}<0.001)$

Tablo 4'de, deney/ kontrol grubu iletişim becerileri sontest bağımsız gruplar t testi yapılmıştır. Deney ve kontrol grubu sontest puanları arasında deney grubu lehine anlamlı fark bulunmuştur $[\mathrm{t}(66)=-36.2, \mathrm{p}<0.001]$.

Tablo 5: Deney grubu iletişim becerileri öntest, sontest, kalıcılık puanlarına ait tekrarlı ölçümler ANOVA testi

\begin{tabular}{llllcc}
\hline DG & N & $\bar{X}$ & SS & f & p \\
\hline Öntest & 34 & 2.636 & .271 & 1250.717 & $\mathbf{. 0 0 0 *}$ \\
Sontest & 34 & 4.143 & .150 & & \\
\hline
\end{tabular}


Karacil-Kılıçaslan \& Yayla (2018)

\begin{tabular}{llll}
\hline Kalıclliktesti & 34 & 4.204 & .146
\end{tabular}

$(* \mathrm{p}<0.001)$

Tablo 5'de, deney grubu iletişim becerileri tekrarlı ölçümler ANOVA testi yapılmıştır. Deney grubu öntest, sontest, kalıcılık testi puanları arasında anlamlı fark bulunmuştur $\mathrm{p}<0.001$.

Tablo 6: Deney grubu iletişim becerileri öntest, sontest, kalıcılık karşılaştırılmasına yönelik tekrarlı ölçümler ANOVA Bonferroni testi

\begin{tabular}{lcccccc}
\hline $\begin{array}{c}\text { Varyansın } \\
\text { Kaynağı }\end{array}$ & $\begin{array}{c}\text { Kareler } \\
\text { Toplamı }\end{array}$ & sd & $\begin{array}{c}\text { Kareler } \\
\text { Ortalaması }\end{array}$ & f & p & $\begin{array}{c}\text { Anlamlı } \\
\text { Fark }\end{array}$ \\
\hline Denekler & 1.234 & 33 & .037 & 1250.717 & $\mathbf{. 0 0 0 *}$ & $\mathbf{2 - 1 , 3 - 1 , 3 - 2}$ \\
Ölçüm & 56.034 & 1.114 & 50.334 & & & \\
Hata & 1.479 & 36.750 & .040 & & & \\
Toplam & 58.767 & 70.864 & & & & \\
\hline *p<0.001) & \multicolumn{2}{c}{ 1:Öntest } & 2:Sontest & 3:Kalıc1lı testi & &
\end{tabular}

Tablo 6'da, deney grubu iletişim becerileri karşılaştırmasına yönelik tekrarlı ölçümler ANOVA testi yapılmıştır. Deney grubu öntest, sontest, kalıcılık testi puanları arasında anlamlı fark bulunmuştur $\mathrm{f}(1.114,36.750)=1250.717, \mathrm{p}<0.001$.

\section{sonuçları}

Deney grubu iletişim becerileri kalıcılık testi odak grup görüşmesi içerik analizi

İletişim becerileri maddeleri “anlayış, sabır, hoşgörü, öz güven, kendini ifade etme, eleştirme, dinleme, beden dili, ses tonu, konuşma, anlaşılma, özür dileme, sosyallik." kategoriler olarak belirlenmiştir. İçerik analizinde;

"Anlayış" bakımından,10 öğretmen adayının 8'unda olumlu katkı sağladığı, 2 öğretmen adayında değişiklik olmadığı, "Sabır" bakımından, 10 öğretmen adayının hepsinde olumlu katkı sağladığ1, "Hoşgörü" bakımından, 10 öğretmen adayının hepsinde olumlu katkı sağladığı, "Empati" bakımından, 10 öğretmen adayının hepsinde olumlu katkı sağladığı, "Öz güven" bakımından, 10 öğretmen adayının 9'unda olumlu katkı sağladı̆̆ı, 1 öğretmen adayında değişiklik olmadığı, "Kendini ifade etme" bakımından, 10 öğretmen adayının hepsinde olumlu katkı sağladığı, "Eleştiri”" bakımından, 10 öğretmen hepsinde olumlu katkı sağladığı, "Dinleme" bakımından, 10 öğretmen adayının hepsinde olumlu katkı sağladığı, "Beden dili” bakımından, 10 öğretmen adayının hepsinde olumlu katkı sağladığı, "Ses tonu" bakımından, 10 öğretmen adayının 9'unda olumlu katkı sağladığı, 1 öğretmen adayında değişiklik olmadığı, "Konuşma" bakımından, 10 öğretmen adayının hepsinde olumlu katkı sağladığı, "Anlaşılma" bakımından, 10 öğretmen adayının 8'sinde olumlu katkı sağladığ1, 2 öğretmen adayında değişiklik olmadığ1, “Özür dileme” bakımından, 10 öğretmen adayının 8'sinde olumlu katkı sağladığı, 2 öğretmen adayında değişiklik olmadığı, "Sosyallik" bakımından, 10 öğretmen adayının hepsinde olumlu katkı sağladığı, tespit edilmiştir. Bu bulgularla ilgili öğretmen adaylarının vermiş olduğu örnek cümleler aşağıdaki gibidir:

D4. Etkili iletişim dersinde grup içerisinde dinleme ve konuşma, beden dili stratejilerimin daha iyi geliştiğini düşünüyorum. Eskiden kendimi ifade ederken kesin 
Yaratıcı Drama Yönteminin Öğretmen Adaylarının İletişim Becerilerine Etkisi

cevaplar verirdim ve surat ifadem çok sertti. Yaratıcı drama etkinliklerinde beden dilimin jest ve mimiklerimin daha çok farkına vardım.

D7. Eskiden kaybetmek, bu fikre alışmak benim için daha zordu. Hemen suratım asıliyordu. Yaratıcı drama uygulamalarında özellikle oyun aşamasında kazanmak için çabaladığım halde kaybettiğimde grup arkadaşlarımın desteğiyle kendimi daha iyi hissetmeye başladı ve kazanan gruba saygı duyup tebrik etmenin, arkadaşlıkları daha da pekiştirdiğini hissettim.

D9. Yaratıcı drama yöntemiyle etkili iletişim dersini isledik. Bir dersin bu kadar zevkli geçeceğini ve bana bir şeyler katacă̆ını tahmin etmedim. En önemlisi arkadaş sayım artt. Sosyal oldum. Son sınıftayım ama sınıfta selam vermediğim arkadaşlarım vardı. Her hafta farklı grupla olmam konuşmadığım arkadaşlarımla konuşmama sebep oldu. önemli benim için.

D8.Yaratıcı drama uygulamalarında gerek bireysel gerek grupla etkinliklere katılmam öz güven gelişimi açısından bana çok şey kattı. Öz güvenim arttıkça toplum içerisinde kendimi daha iyi ifade etmeye başladım. Iletişimim daha iyi oldu.

Tekrarlı ölçümler ANOVA iletişim becerileri kalıcılık testinden elde edilen sonuçlar ile, odak grup görüşmesi içerik analizinde elde edilen sonuçlar uyumluluk arz etmektedir. Bu durum kalıcılık testinin güvenilirliğini ortaya koymaktadır. Aynı zamanda kalıcılık testi iki veriden de elde edilen sonuçlar, yaratıcı drama yönteminin öğretmen adaylarının iletişim becerileri gelişimi üzerindeki olumlu etkisini ve kalıcılı̆̆ını göstermektedir.

Süreç sonunda kontrol grubundaki öğretmen adaylarıylarının da görüşleri alınmıştır. Görüşler doğrultusunda genel olarak düz anlatım yoluyla işlenen iletişim dersinin öğretmen adaylarının iletişim becerilerinin gelişimi üzerinde çok fazla etkisinin olmadığı tespit edilmiştir. Bu sonuç yaratıcı drama yönteminin öğretmen adaylarının iletişim becerileri üzerinde düz anlatıma göre daha etkili olduğunu kanıtlar niteliktedir.

\section{Sonuç ve Tartışma}

Deney/ kontrol grubu öğretmen adaylarının iletişim becerileri öntest puanları arasında anlamlı fark yoktur. Bu sonuç, istatistiksel olarak deney ve kontrol grubunun, iletişim becerileri öntest puanları arasında anlamlı farklılığın olmadığını göstermektedir. Deney/ Kontrol gruplarının, iletişim becerileri ölçme aracı öntest puanları arasında anlamlı fark bulunmaması olması istenen durumdur. Çünkü deneysel çalışmaya başlamadan önce öğrencilerin iletişim becerileri giriş davranışları açısından denk olması, yapılan çalışmanın güvenilirliğini artırmaktadir.

Deney grubu iletişim becerileri öntest, sontest puanları arasında sontest lehine anlamlı fark vardır. Ortalamalar incelendiğinde deney grubu sontest ortalaması, öntestin yaklaşık iki katı kadar artmıştır. Bu bulgu deney grubuna yaratıcı drama ile verilen eğitimin öğretmen adaylarının iletişim becerilerini artırmada etkili olduğunu göstermektedir.

Kontrol grubu iletişim becerileri öntest, sontest puanları arasında sontest lehine anlamlı fark vardır. Bu anlamlı farkın çeşitli etkenlerden kaynaklandığı düşünülebilir. Bu etkenlerden biri her iki grupta da dersin gerekliliklerinin yerine getirilmesi, her iki grupta da dersin işlenmiş olması olabilir. Kontrol grubunda ders geleneksel yöntemle, deney grubunda ise yaratıcı drama yöntemiyle işlenmiştir. Diğer bir etken isen, ölçülen davranışın bilgi odaklı olmaması, tam tersine 
tutum temelli olması olabilir. Bu nedenlerle, kontrol grubu son test ortalamasının öntest ortalamasından istatistiksel olarak az da olsa artmış olması beklenen bir durumdur. Ancak ortalamalara baktığımızda çok fazla artış gözlenmemiştir. Oysa deney grubu son test ortalaması öntestin yaklaşık iki katı kadar artmıştır. Kontrol grubunda bu artışın çok az olduğu görülmektedir. $\mathrm{Bu}$ bulgu kontrol grubuna geleneksel yöntemle verilen eğitimin öğretmen adaylarının iletişim becerilerini geliştirmede yaratıcı drama yöntemi kadar etkili olmadığını göstermektedir.

Deney/ kontrol grubu öğrencilerinin iletişim becerileri sontest puanları arasında deney grubu son test lehine anlamlı fark vardır. Aritmetik ortalamalar incelendiğinde deney grubu sontest ortalaması, kontrol grubu sontest puan ortalamasının yaklaşık iki katı kadardır. Bu durum öğretmen adaylarının iletişim becerileri gelişiminde yaratıcı drama yöntemin geleneksel yöntemden daha etkili olduğunu göstermektedir.

Analizler sonucunda yaratıcı drama yönteminin öğretmen yeterliklerinden kişisel ve mesleki gelişim, yeterlik ve performans göstergesi olan iletişim becerileri gelişimi üzerinde geleneksel yönteme göre daha etkili olduğu tespit edilmiştir. Alanyazına bakıldığında; yaratıcı drama uygulamalarının, sosyal beceri gelişiminde (Aslan, Erbay ve Saygın, 2010; Ceylan ve Ömeroğlu, 2007; Çevik, 2006; Duatepe -Ubuz, 2004; Kara ve Çam, 2007; Kaf-Hasırcı, Bulut ve Saban, 2007; Pomerantz, 2003) iletişim becerileri gelişiminde (Akoğuz, 2002; Rances, 2005; Karateke, 2006; Wardrope 2002; Arslan. E. Erbay F, Saygın, 2010; Kılıç, 2012; Öztürk, 2006; Uşakl1, 2011; McNaughton, 2004), empatik beceri ve empatik eğilim düzeylerinde (Gökçearslan Çifci ve Altınova, 2012) olumlu etkisinin olduğu görülmektedir.

Tanrıseven ve Aykaç (2013) çalışmalarında, yaratıcı dramanın üniversite öğrencilerinin, kişisel ve mesleki yaşantılarına katkısını incelemişlerdir. Nitel araştırma yöntemi an bu çalışmada betimsel analiz yapılmıştır. Çalışma sonucunda, etkinliklere katılan bireylerin görüşleri, yaratıcı drama uygulamalarının kişisel ve mesleki hayatlarında kendilerine katkı sağlayacağıdır. Aynı zamanda çalışmadan elde edilen veriler, yaratıcı drama çalışmalarının, bireylerin zamanı etkili kullanma ve sosyal becerileri üzerinde olumlu etkileri olduğunu kanıtlamışlardır. Yaratıcı drama uygulamaları kendini daha rahat ifade edebilme, iletişim kurma, gruba uyum sağlama ve empati kurma yönünde bireylere katkı sağlamıştır. Görüldüğü gibi alan yazında yer alan çalışma sonuçları, bu araştırmanın sonuçlarını destekler niteliktedir. Bu durum yaratıcı drama yönteminin öğretmen yetiştirmedeki önemini kanıtlar niteliktedir. Bu araştırma sonuçları doğrultusunda, eğitimde başarıyı sağlamak ve nitelikli eğitim için, öğretmen yetiştirme sürecinde, öğretmen yeterliklerinden; iletişim becerilerini gelişimi sağlama da, yaratıcı drama yöntemi ve uygulamalarından yararlanılması, öğretmenin başarısını, gelişimini, dolayısıyla öğrencinin başarısını gelişimini olumlu yönde etkileyecektir. Sonuç olarak, yaratıcı drama yönteminin öğretmen adaylarında bulunması gereken iletişim becerileri gelişimi üzerinde oldukça önemli bir işlevinin olduğu görülmektedir.

Araştırmanın sonuçlarına dayanılarak şu öneriler getirilebilir:

1998 yılında uygulanan, 2005 eğitim programlarındaki değişiklikle, 2006 yılında güncellenen, ve son olarak 2017 yılında tekrar güncellenen "Öğretmenlik Mesleği Genel Yeterlikleri” incelediğinde, öğretmenlerde bulunması gereken kişisel ve mesleki gelişim performans ve yeterlik göstergesi olan iletişim becerilerinin her dönemde MEB öğretmen yeterliklerinde yer aldığı görülmüştür. Ancak, öğretmen eğitiminde kişisel ve mesleki gelişim için yapılan uygulamaların arka plana atıldığı, öğretmen yetiştirirken daha çok alan bilgisi ve 
Yaratıcı Drama Yönteminin Öğretmen Adaylarının İletişim Becerilerine Etkisi

teorik bilgilere ağırlık verildiği görülmektedir. Yapılan bu araştırmadan elde edilen bulgular, uygulamalı yöntem olan yaratıcı dramanın, öğretmen adaylarının kişisel ve mesleki gelişimin önemli boyutu olan iletişim becerilerinde önemli rol oynadığı görülmektedir. Bu bağlamda Lisans öğretmen yetiştirme programlarındaki derslerin ve ders içeriklerinin, öğretmen adaylarının, meslekte kazanmaları gereken yeterliklere ve ihtiyaçlarına göre düzenlenip, bu yeterliklerin uygulamalı yöntemlerle işlenmesi ve derslerin uygulamalarla desteklenmesi, öğretmenlerin kişisel ve mesleki gelişimlerine, dolayısıyla etkili iletişim becerilerinin gelişmesine katkı sağlayabilir. Dolayısıyla uygulamalı yöntem olan yaratıcı drama, öğretmen yetiştirme de mesleğe yönelik her derste kullanılmalıdır.

\section{Referanslar}

Adıgüzel, H. Ö. (2013). Ĕ̆itimde yaratıcı drama. (8.Baskı). Ankara: Pegem Akademi Yayıncilik.

Akoğuz, M. (2002). Iletişim becerilerinin geliştirilmesinde yaratıcı dramanın etkisi. Ankara Üniversitesi Eğitim Bilimler Enstitüsü: Yayımlanmamış yüksek lisans tezi.

Arslan, E., Erbay, F. \& Saygın, Y. (2010). Yaratıcı drama ile bütünleştirilmiş iletişim becerileri eğitiminin çocuk gelişimi ve eğitimi bölümü öğrencilerinin iletişim becerilerine etkisinin incelenmesi. Selçuk Üniversitesi Sosyal Bilimler Enstitüsü Dergisi, 23, 1-8.

Balcı-Çelik, S. \& Ersanlı, K. (1998). İletişim becerileri envanterinin geliştirilmesi: Geçerlik ve Güvenilirlik Çalışması. Türk Psikolojik Danışma ve Rehberlik Dergisi, 2(10), 7 12.

Bayraktar, A., Okvuran, A. (2012). Improving students writing through creative drama. Procedia-Social and Behavioral Sciences, 51, 662-665.

Bell, E. (2008). Theories of performance. California: SAGE Publications.

Ceylan, Ġ., Ömeroğlu, E. (2007). Okulöncesinde drama dersinin üniversite öğrencilerine katkısının bazı değişkenlere göre incelenmesi. Yaratıcı Drama Dergisi, 1(3-4), 57-77.

Creswell, J. W. (2008). Educational research planning, conducting and evaluating quantitative and qualitative research. International Pearson Merril Prentice Hall.

Çevik, H. (2006). Çocuklara yabancı dil öğretiminde drama tekniğinin kullanımı. Çukurova Üniversitesi Sosyal Bilimler Enstitüsü: Yayımlanmamış yüksek lisans tezi.

Dilekmen, M., Başc1, Z. Bektaş, F. (2008). Eğitim fakültesi öğrencilerinin iletişim becerileri. Atatürk Üniversitesi Sosyal Bilimler Enstitüsü Dergisi, 12(2), 223-231.

Dowd, T. \& Teirney, J. (2005). Teaching social skills to youth: A step-by-step quide to 182 basic to comple skills plus helpful techniques(2nd Edition). Boys Town. Ne: Boys Town Press

Duatepe, A. \& Ubuz, B. (2004). Drama temelli geometri ders planlarının geliştirilmesi ve uygulanması. Sabancı Üniversitesi Ë̆itimde İyi Örnekler Konferansl, 17-18 Ocak, Sabancı Üniversitesi, İstanbul 
Elkatmış, M. (2015). Yazılı ve sözlü anlatım ile etkili iletişim derslerinin sınıf öğretmeni adaylarının iletişim becerilerine etkisinin incelenmesi, 14(4), 1341-1351, [Çevrim İçi: http://ilkogretim-online.org.tr]. Erişim Tarihi: 19 Kasım 2017.

Ergin, A. \& Birol, C. (2000). Eğitimde iletişim. Ankara: Anı Yayıncılık.

Gökçearslan, Ç.E. \& Altınova, H. (2012). Sosyal hizmet eğitiminde yaratıcı drama yönteminin öğrencilerin empati becerisine etkisi. Ankara Să̆lık Bilimleri Dergisi, 1(2), 133-149.

Kaf-Hasırcı, Ö., Bulut, M. S. \& İflazoğlu-Saban, A. (2008). Öğretmen adaylarının yaratıcı dramanın bireysel ve akademik kazanımlarına ilişkin görüşleri. Yaratıcı Drama Dergisi, 3(6), 63-83.

Kara, Y. \& Çam, F. (2007). Yaratıcı drama yönteminin bazı sosyal becerilerin kazandırılmasına etkisi. Hacettepe Üniversitesi Ĕ̆itim Fakültesi Dergisi, 32, 145-146.

Karacil, M. (2009). İlköğretim 1. kademede yaratıcı drama yönteminin ögrrencinin akademik başarısına etkisi. Kafkas Üniversitesi Sosyal Bilimler Enstitüsü: Yayımlanmamış yüksek lisans tezi.

Karateke, E. (2006). Yaratıcı dramanın ilköğretim 1.kademede 6.sınıf ögrencilerinin yazılı anlatım becerilerine olan etkisi. Mustafa Kemal Üniversitesi Sosyal Bilimler Enstitüsü: Yayımlanmamış yüksek lisans tezi.

Kılıç, B. (2012). İlköğretim okullarında uygulanan mesleki çalışmalarda yaratıcı drama uygulamasının öğretmenlerin iletişim becerilerine etkisi, Yaratıcı Drama Dergisi, 7(14), $38-47$.

Lavasani, M. G., Afzali, L. \& Afzali, F. (2011). Cooperative learning and social skills. Cypriot Journal Of Educational Science, 4,186 -193.

Mantione, R. \& Smead, S. (2003). Weaving through words: Using the arts to teach reading comprehension strategies. Inernational Reading Association: Delaware, The USA.

Mcnaughton, M. J. (2004). Educational drama in the teaching of education for sustainability. Enviromental Education Research, 10(2), 139-155.

MEB (Milli Ĕgitim Bakanlı̆̆ı), (2017).Öğretmenlik mesleği genel yeterlikleri. [Çevrim İçi:http://oygm.meb.gov.tr/www/ogretmenlik-meslegigenelyeterlikleri/icerik/].Erişim Tarihi: 15 Eylül 2017.

Namdar, A. O. \& Camadan, F. (2016). Yaratıcı drama uygulamalarının öğretmen adaylarının sosyal becerilerine etkisi. Gazi Üniversitesi Gazi Ĕ̆itim Fakültesi Dergisi, 36(3), 557 575.

Oğuz, A. (2009). Öğretmen adaylarının sözlü ve yazılı anlatım becerilerine ilişkin öz yeterlik algıları. Elektronik Sosyal Bilimler Dergisi, 8(30), 18-42.

Öztürk, A. (2006). Öğretmen Yetiştirmede Yaratıcı Drama Yöntemiyle İşlenecek Tiyatro Dersinin Öğretmen Adaylarındaki Sözel İletişim Becerilerine Etkileri. H. Ö. Adıgüzel (Ed.). Yaratıcı Drama Yazıları 1985-1998. Ankara: Naturel Yayıncılık. 
Yaratıcı Drama Yönteminin Öğretmen Adaylarının İletişim Becerilerine Etkisi

Pomerantz, A. M., (2003). Who plays client? Collaborating with theatre departments to enhance clinical psychology role-play training exercises. Journal of Clinical Psychology, 59, 363-368.

Rances, J. N. (2005). Student perceptions of improving comprehension through drama as compared topeotry and fiction in college english freshman composition courses. Widener University.Chester, Pa. Retrieved From [Çevrim İçi: http://www.oecd.org/dataoecd/39/47/34990905.pdf]. Erişim Tarihi: 19 Eylül, 017.

Saçlı, F. (2013). Yaratıcı drama ĕgitiminin aday beden eğitimi öğretmenlerinin eleştirel düşünme becerileri ve eğilimleri üzerine etkisi. Hacettepe Üniversitesi: Yayımlanmamış doktora tezi.

Sazak P. E. \& Sucuoğlu, B. (2013). The outcomes of a social skills teaching program for 1nclusive classroom teachers. Educational Sciences: Theory \& Practice, 13(4), $2247-$ 2261.

Tabachnick, B. G. \& Fidell, L. S. (2007). Using multivariate statistics, 5th ed. Boston, MA,: Allyn \& Bacon/Pearson Education.

Tanrıseven, I. \& Aykaç, M. (2013). Üniversite öğrencilerinin yaratıcı dramanın kişisel ve mesleki yaşantılarına katkısına ilişkin görüşleri. Adlyaman Üniversitesi Sosyal Bilimler Enstitüsü Dergisi, 6(12), 329-348.

Tuğrul, B. (2003). Drama ve öğrenme öğretme A. Öztürk (Ed.) Çocukta yaratıcılık ve drama, 121-128. Eskişehir: Anadolu Üniversitesi Yayınları.

Uşaklı, H. (2011). Drama ve iletişim becerileri. Ankara: Nobel Yayıncılık.

Üstündağ, T. (2004). Yaratıcı drama öğretmenin günlüğ̈̈. Ankara: Pegem Akademi Yayıncilik.

Üstündağ, T. (2007). İletişim sürecinde yaratıcı drama. Aslan, Naci (Ed.), Dramaya çok yönlü bakış, 29-35. Ankara: Oluşum Yayınları.

Wardrope, W. J. (2002). Department chairs' perceptions of importance of business comunacations kills. Business Communication Quarterly, 65(4),60-72. Washington.

World Bank, (2005). Learning to teach in the knowledge society. Final Report. By Task Manager Juan Manuel World Bank.

Yaman, E. \& Aydın, O. (2015). Idealist ögretmen. Ankara: Tdn Yayıncılık. 